\title{
STRATEGI SURVIVAL OF THE FITTEST SANTRI PEKERJA BURUH PABRIK ROKOK DI PT. DJARUM KUDUS
}

\author{
SURVIVAL OF THE FITTEST STRATEGY \\ SANTRI WORKERS IN PT. DJARUM KUDUS CIGARETTE FACTORY
}

\author{
Mas'udi \\ Institut Agama Islam Negeri Kudus \\ Jl. Conge Ngembalrejo PO. Box. 51 Kudus 59322 \\ Email: msd.jufri@gmail.com
}

Naskah diterima tanggal 8 Maret 2019, Naskah direvisi tanggal 27 April 2019, Naskah disetujui tanggal 30 Mei 2019

\begin{abstract}
Abstrak
Kehidupan para santri yang bekerja sebagai buruh di Pabrik Rokok PT. Djarum Kudus sangat terikat dengan doktrin agama yang mereka yakini kebenarannya. Dalam kesadaran doktrin agama yang mereka yakini pula, mereka dituntut untuk bekerja secara berdisiplin sebagai buruh di Pabrik Rokok PT. Djarum Kudus. Penelitian ini adalah bagian dari penelitian antropologi dengan fokus metodisnya penelitian kualitatif. Observasi partisipasi, wawancara, dan dokumentasi, menjadi bagian pengumpulan data untuk merumuskan penelitian ini memeroleh data lapangan yang dirancang. Penelitian ini berlangsung di antara tahun 2015 sampai 2018. Kehidupan para santri yang bekerja sebagai buruh di PT. Djarum Kudus dapat berjalan sesuai dengan peraturan yang sudah ditentukan agama. Kondisi ini berjalan beriringan dengan realitas kehidupan pabrik yang selalu menuntut mereka untuk bekerja secara berdisiplin. Keterpaduan hidup ini mewujud secara seksama dalam kehidupan para santri yang bekerja sebagai buruh Pabrik Rokok di PT. Djarum Kudus dengan kesadaran mereka untuk selalu menjadi pribadi yang harus bekerja, mengaji, dan berdagang. Perspektif Gusjigang — anak bagus, pandai mengaji, dan gemar berdagang-menjadi konstruksi kesadaran para santri guna selalu menyadari hidup dalam keterpaduan sosial yang lebih baik.
\end{abstract}

Kata Kunci: aktualisasi diri, pengajian, keagamaan, kearifan lokal, pendidikan moral

\begin{abstract}
The life of santri as factory labor at the cigarette factory of PT. Djarum Kudus was bound with their religious doctrines as they believe. According to their religious doctrine consciousness, they obligate to work more disciplines as PT. Djarum Kudus factory workers. This research is part of anthropological analysis which is focus to the design of qualitative approach. The observation of participant, interview, and documentation used as the methods on collecting data. This research has run between 2015 until 2018. The life of Islamic student boarding school as they get a job to be factory labor was run well based on the religious rules. This situation run together with the factory labor rules as hoped them to get a discipline on job. The integration of this life was manifested inside of Islamic student boarding school as they get a job to be factory labor of PT. Djarum Kudus with their consciousness to be personally working, studying, and trading. The perspective of Gusjigang-good student, clever on study, and diligent on trade-constructed the self-consciousness of them as they used to understand life on good social integration.
\end{abstract}

Keywords: self-actualization, study, religiosity, local wisdom, moral education 


\section{PENDAHULUAN}

$\mathrm{K}$ ajian tentang survival of the fittest keberlangsungan hidup merupakan kajian yang dirumuskan oleh Herbert Spencer dari pengaruh kuat pemikiran Charles Darwin. Dasar pemikiran atas perspektif ini ditengahkan oleh Ken Plummer bahwa masyarakat mengalami perkembangan layaknya tubuh hewan. Seperti layaknya tubuh yang memiliki struktur yang dapat dikenali (jantung, otak, kulit, kaki, hati), begitu juga dengan masyarakat yang memiliki struktur-struktur seperti ekonomi, sistem politik, sistem hukum, keluarga, dan agama. Lebih lanjut, survivalitas masyarakat diilustrasikan layaknya tubuh yang memiliki struktur dengan fungsi-fungsi yang jelas (jantung untuk memompa darah, otak untuk menyelaraskan tindakan dan memberikan kecerdasan, hati untuk membersihkan tubuh), begitu juga masyarakat yang memiliki strukturstruktur fungsional-ekonomi membantu masyarakat menata penghasilan dan beradaptasi dengan lingkungan, politik membantu masyarakat mencapai tujuan, komunitas membantu menyosialisasikan dan memadukan unsur-unsur yang berbeda, dan hukum mengatur serta mengendalikan masyarakat (Plummer, 2013: 43-44).

Perspektif keberlangsungan hidup sebagaimana Plummer ungkapkan, menunjuk kepada fakta dinamis kehidupan ini yang selalu berjalan di antara fenomena-fenomena yang melingkupi. Evolusi menjadi sebuah fakta peristiwa yang keberadaannya menjelaskan masyarakat senantiasa menjumpai perubahan. Perspektif evolusi dalam pandangan Wendy Northcutt merumuskan sebagai proses sebuah spesies mengubah diri dari suatu kondisi kepada yang lain guna menjejak kepada lingkungan yang lebih baik. Pada perspektif lain evolusi menjelaskan tentang bagian dari proses keberlangsungan hidup (Northcutt, 2001: 11).

Proses keberlangsungan hidup yang terwujud dari konsep evolusi berkaitan erat dengan interaksi yang ada dalam hukum sosial yang berjalan. Dalam titik keberlangsungan hidup ini setiap unsur yang berinteraksi di lingkup sosial perlu menyadari bahwa antara satu unsur sosial dengan unsur sosial yang lain, mustahil berjalan sendiri-sendiri. Secara garis besar, dalam pertumbuhan sosial yang berjalan, setiap individu akan dipertemukan dengan strata-strata sosial yang kenyataannya juga muncul guna mengamati tingkat variasi dalam masyarakat. Menguraikan fenomena ini, Peter Burke mencoba mengilustrasikan bahwa struktur sosial yang terjadi di masyarakat akan berjalan di antara hierarki yang terjadi di tengahtengah mereka. Hierarki sosial tradisional didasarkan pada kelahiran ascription dan mobilitas sosialnya rendah. Sebaliknya, hierarki modern didasarkan pada merit prestasi dan mobilitas sosialnya tinggi. Sebuah masyarakat estates (sistem tuan tanah, lord) telah digantikan oleh masyarakat yang terdiri atas kelas-kelas, yang memiliki kesempatan yang setara. Selain itu, dalam masyarakat tradisional, unit dasarnya adalah kelompok kecil yang di dalamnya saling kenal, atau disebut komunitas gemeinschaft. Namun, setelah adanya konsep modernisasi, inti dasarnya adalah masyarakat luas yang impersonal gesellschaft (Burke, 2015: 214).

Kemunculan hierarki sosial yang terjadi di masyarakat memang tidak bisa dijauhkan dari dinamika perubahan masyarakat itu sendiri. Dalam hal ini Pip Jones mencoba menengahi bahwa pengaruh terpenting terhadap kehidupan sosial adalah distribusi keberuntungan dan dampaknya pada perilaku. Apabila keberuntungan itu tersebar secara tidak merata, kesempatan orang-orang yang beruntung untuk memilih bagaimana berperilaku jauh lebih besar daripada orang-orang yang tidak beruntung (Jones, 2009: 13).

Dinamika sosial yang berjalan di masyarakat dengan struktur-struktur sosial yang berjalan di tengah-tengahnya, menjadi bukti bahwa terjadi perubahan di masyarakat. Studi perubahan sosial dalam pandangan Nanang Martono akan melibatkan dimensi ruang dan waktu. Dimensi ruang menunjuk pada wilayah terjadinya perubahan sosial serta kondisi melingkupinya. Dimensi ini mencakup pula konteks historis yang terjadi pada wilayah tersebut. Dimensi waktu dalam studi perubahan meliputi konteks masa lalu (past), sekarang (present), dan masa depan (future). Konteks waktu lalu merupakan aspek yang harus diperhatikan dalam melakukan studi perubahan 
sosial (Martono, 2014: 3). Penjelasan ini pula diekspresikan Lance Castles dengan menegaskan susunan golongan satu kota terutama ditentukan oleh fungsi ekonominya, dan jika satu kota dikuasai satu industri, keperluan teknis industri tersebut akan benarbenar mempengaruhi struktur sosialnya (Castles, 1982: 87).

Catatan Castles di atas memperjelas kedudukan ekonomi sebagai salah satu faktor bagi perubahan sosial yang terjadi di masyarakat. Pada perspektif kajian antropologi, Sjafri Sairin, dkk., menganalisis ekonomi sebagai suatu kajian budaya. Antropologi ekonomi pada masa awal perkembangannya, identik dengan gejala pertukaran tradisional yang tidak menggunakan mekanisme uang. Pertukaran tersebut terdapat pada masyarakat tradisional, dan peasant, misalnya pertukaran hadiah (gift exchange), dan perdagangan kula". Kurangnya perhatian ahli antropologi terhadap gejala pertukaran yang menggunakan mekanisme uang dipengaruhi oleh kondisi awal perkembangan, antropologi menaruh perhatian kepada masyarakat tradisional dan pedesaan dengan perekonomian sub sistem mereka. Dalam antropologi ekonomi, berbagai pertukaran yang terdapat dalam masyarakat tradisional dan pedesaan yang tidak menggunakan mekanisme uang sering disebut dengan istilah resiprositas dan redistribusi (Sairin, dkk., 2002: 38).

Landasan teoritis tentang antropologi ekonomi yang disampaikan oleh Sjafri Sairin, dkk., di atas menunjukkan bahwa kegiatan ekonomi yang berjalan di tengah-tengah kehidupan masyarakat banyak bersandar kepada nilai-nilai resiprositas dan redistribusi yang berjalan. Kondisi yang terjadi di masyarakat tersebut dapat diamati pula pada aktivitas buruh Pabrik Rokok PT. Djarum Kudus. Dalam rangka menjual jasa Sigaret Kretek Tangan (SKT), para buruh Pabrik Rokok PT. Djarum Kudus berinteraksi kuat dengan perusahaan sehingga jasa yang mereka alokasikan mendapatkan pertukaran upah setimpal. Besaran upah yang mereka perolehi di pabrik sangat terkait dengan etos kerja yang bisa diwujudkan dalam menyampaikan jasa pekerjaan masing-masing. Untuk itulah, para santri buruh Pabrik Rokok di
PT. Djarum Kudus, selalu menyadari bahwa etos kerja dan nilai-nilai keagamaan di tengah-tengah mereka merupakan situasi-situasi yang mustahil dikesampingkan. Kesadaran untuk memenuhi kebutuhan keluarga sebagai niatan untuk ibadah menjadi bagian umum yang dijumpai dalam usaha pemenuhan kerja sebagai buruh pabrik rokok. Kesadaran etos kerja dan kolaborasi agama merupakan asas faktual yang tidak mungkin dikesampingkan sebagaimana hal ini disampaikan Mudrajad Kuncoro (2014) bahwa perkembangan di suatu wilayah dipengaruhi salah satunya oleh aspek geografis, budaya, dan institusi yang mengitarinya.

Menjelaskan etos kerja masyarakat Jawa secara umum dan Kudus secara khusus dapat dilihat pada deskripsi-deskripsi kebudayaan yang berkembang di tengah-tengah masyarakat Jawa. Etos kerja sebagai tenaga linting yang banyak dilakukan oleh para perempuan Jawa merupakan gambaran-gambaran klasik yang telah dituliskan para sejarawan Indonesia. Dalam sebuah ilustrasi sastrawi yang ditulis oleh Sigit Budhi Setiawan dan Marlutfi Yoandinas (Setiawan dan Yoandinas, 2013: 23-24) disebutkannya:

Etos kerja seorang perempuan Jawa dengan aneka ragam kerja yang dilakukan. Perempuan tersebut disebutkan Mbah Ponco. Mbah Ponco, adalah janda kelahiran 1935 di Gunung Kidul, Daerah Istimewa Yogyakarta. Harinya dimulai sebelum suara adzan Subuh berkumandang dan solah-solah sayup terdengar dari rumahnya. Begitu terjaga dari tidurnya, Mbah Ponco bersegera ke dapur untuk minum air putih, memasak air hangat untuk kopi dan teh. Dia menikmati minuman hangat di pagi hari sebagai teman kegemarannya merokok. Ketika beres, dia merendam pakaian yang akan dicuci. Tak lupa lampu-lampu penerangan di malam hari dimatikannya. Kadang jika kambing peliharaannya mengembik, dia akan segera ke kandang, melihat keadaan atau sekadar menambah makanan untuk peliharaannya. Dia tidak pernah mengeluh, jika setiap hari harus terjaga sedini itu. Terlebih pada tengah malam Mbah Ponco sudah bangun untuk shalat malam. Sebagai perempuan sepuh, dia merasakan semakin bertambah umur semakin berkurang jatah tidurnya. Dia pikir hal itu alamiah, selain ada keinginan di dalam dirinya untuk selalu dekat kepada Tuhan. 
Untuk selanjutnya, melihat perwujudan agama dalam lintasan sosial masyarakat Kudus yang umum dikenal dengan masyarakat santri, agama dalam kehidupan mereka menjadi lokomotif utama untuk menuntun laju hidup dan penghidupan yang mereka jalankan. Prinsip dasar kehidupan santri adalah menjadikan agama sebagai modal diri yang selalu dihadirkan dalam kehidupan sosial kemasyarakatan. Mudjahirin Thohir menguraikan bahwa di kalangan santri, agama dilihat dalam fungsinya sebagai pedoman (hudan) yang berisi pengetahuan tentang nilainilai, norma-norma, aturan-aturan, yang dianggap benar dan baik, yang dilawankan dengan yang keliru, dan tidak-baik, sehingga manusia bisa menjalankan kehidupannya sesuai dengan nilai-nilai kemanusiaan (Thohir, 2006: 137). Konstruksi ini menjelmakan hakikat diri santri sebagai insan yang penuh dengan kesabaran dan keikhlasan dalam mengisi ladang amal kehidupan mereka.

Gambaran santri yang lain dijelaskan Zamakhsyari Dhofier dalam uraiannya bahwa santri adalah seseorang yang tinggal di pesantren untuk mempelajari kitab-kitab klasik (Dhofier, 2011: 88). Perspektif ini menjadi gambaran umum yang dipersepsikan masyarakat bahwa keberadaan seorang santri identitas kehidupannya adalah pondok pesantren. Pondok pesantren merupakan tempat tinggal di dalamnya para santri belajar meneguhkan hakikat pendidikan moral dan perilaku beragama (tarbiyah al-'ilm fiddiin). Hal ini menjadi berbeda dalam perspektif yang digambarkan oleh Abdurrahman Mas'ud atas keumuman Kyai Kudus yang tidak banyak memiliki pesantren (Mas'ud, 2013: 68). Namun pada sisi yang lain, mayoritas dari mereka memiliki jamaah-jamaah rutin yang ikut serta dalam banyak pengajian yang dilaksanakan. Dari konstruks yang tergambar pada fenomena kehidupan sosial masyarakat di Kudus ini, terminologi santri dihubungkan kepada orang-orang yang aktif dalam kegiatan pengajian-pengajian kemasyarakatan, manakiban, dan berzanjenan.

Keterlibatan para santri yang bekerja sebagai buruh Pabrik Rokok di PT. Djarum Kudus mengundang perhatian besar dalam rangka menganalisis kehadiran agama bagi stabilitas kehidupan perburuhan yang dijalankan. Aspek-aspek pertahanan sosial yang mereka bangun dalam rangka menunjang perekonomian keluarga di tengah-tengah himpitan ekonomi dan regulasi pabrik yang cukup ketat serta perwujudan agama yang harus senantiasa diwujudkan, keseluruhannya menjadi latar belakang kajian yang penting untuk dieksplorasikan. Pada bagian lain, kondisi historis Kota Kudus sebagai kota religi dengan semangat filosofi masyarakatnya Gusjigangsantri yang bagus, pandai mengaji, dan rajin berdagang - mengambil poin kajian yang cukup penting untuk disinkronisasikan dengan perspektif lain dari kota ini sebagai kota kretek.

\section{Tinjauan Pustaka}

Kajian tentang dinamika kehidupan buruh pabrik bukanlah fakta baru dalam lintasan akademik. Penelitian tentang kaum buruh menjadi sebuah kajian yang cukup penting untuk selalu dibahas mengingat kenyataannya terkandung kepentingan masyarakat banyak dan sering kali kepentingan-kepentingan yang ada baik sifatnya individual dan sosial, terkooptasi tekanan-tekanan korporasi. Keberadaan para santri yang bekerja sebagai buruh Pabrik Rokok di PT. Djarum Kudus menjadi unik untuk dianalisis kondisi sosial keagamaan mereka mengingat aktivitas di pabrik juga bisa tampak rentan dari kemungkinan-kemungkinan tekanan yang ada. Kondisi ini sebagaimana juga tergambar dari penjelasan Bambang T.D., dkk., "Buruh Menuliskan Perlawanannya" (Bambang, dkk., 2015) yang menjelaskan bahwa para buruh selalu dihadapkan kepada tuntutan untuk bersikap berani dan mampu memperjuangkan semua hak-hak individualitasnya. Para buruh dituntut untuk bertahan dalam laju hegemoni perusahaan yang kurang berpihak. Dasar analisis Bambang T.D., dkk., tentu lebih menitikberatkan kepada usaha para buruh untuk menyadari hak asasinya yang selalu harus diperjuangkan. Kajian ini tidak melihat aspek-aspek mendasar latar belakang para buruh yang beraneka ragam. Secara menyeluruh penelitian ini berbeda dari kajian strategi survival the fittest para santri yang bekerja sebagai buruh Pabrik Rokok di PT. Djarum Kudus. 
Gambaran berbeda juga bias dilihat pada dinamika kehidupan kaum buruh yang memiliki tingkat kepadatan kerja mereka sehari-hari. Secara seksama pula segudang pekerjaan yang diembannya memunculkan dampak-dampak yang bervariasi. Perekonomian menjadi fenomena umum yang memicu gerak retrospeksi para buruh dalam merespons kehidupan mereka di pabrik. Tidak bias dihindari sebagai akibatnya, belenggu kemiskinan menjadi salah satu bagian yang diakibatkan oleh adanya kehidupan perburuhan. Dian Maulina Wijayanti (2010), dalam penelitiannya tentang "Belenggu Kemiskinan Buruh Perempuan Pabrik Rokok" memotret rendahnya pendidikan kaum buruh, hal tersebut telah menjadikan mereka terjerumus dalam lubang kemiskinan. Penelitian Dian Maulina Wijayanti memotret tentang profil dan latar belakang yang mendorong perempuan bekerja sebagai buruh Pabrik Rokok Janur Kuning Kudus di Desa Piji Kecamatan Dawe. Peneliti menjelaskan bahwa perempuan bekerja sebagai buruh di pabrik rokok didorong oleh kondisi ekonomi keluarga yang terbelenggu dalam kemiskinan dan latar belakang tingkat pendidikan serta keterampilan dan keahlian yang rendah. Analisis Dian Maulina Wijayanti ini tidak selurus atas kajian dalam penelitian ini. Peneliti tidak menganalisis secara mendetail tentang strategi mengurai belenggu kemiskinan yang ada. Hal ini berbeda dengan kajian ini yang melihat bagaimana kondisi pertahanan diri para santri yang bekerja sebagai buruh Pabrik Rokok di PT. Djarum Kudus yang mampu berjalan dalam realitas kehidupan perburuhan yang mengikat.

Penelitian yang dihasilkan Dian Maulina Wijayanti tentu tidak dapat menjadi dasar satu-satunya penyebab belenggu kemiskinan dalam kehidupan para buruh pabrik rokok. Di bagian lain, dunia industri selalu mendatangkan aspek-aspek ketimpangan sosial dalam kehidupan masyarakat. Analisis Oki Rahadianto Sutopo (2013) "Faktor Struktural dan Kultural Penyebab Kesenjangan Sosial: Kasus Industri Batik Pamekasan Madura" menyebutkan pembangunan ekonomi pengandaiannya adalah menghasilkan pemerataan kesejahteraan bagi masyarakat. Namun, dalam perkembangan yang ada, pasca ditetapkan sebagai sentra batik, masyarakat Kecamatan Proppo Pamekasan Madura justru sebaliknya. Tingkat prasejahtera warga berdasarkan alasan ekonomi justru menjadi tertinggi di antara kecamatan yang lain. Melalui wawancara dan observasi yang dilakukannya, peneliti menemukan sebab kesenjangan sosial tersebut, karena reproduksi struktur sosial yang timpang, distribusi kuasa tidak merata, dan timbulnya relasi dominasi subordinasi serta akses atas industri yang tidak merata. Kondisi ketimpangan sosial ini juga diperkuat dengan kultur patriarki yang semakin meneguhkan kesenjangan sosial di masyarakat setempat. Kajian ini memiliki keterhubungan yang erat mengingat lokus penelitian yang tampak sebagai wilayah santri. Namun, kondisi yang ada di Kecamatan Proppo Pamekasan Madura tidak sama dengan kondisi sosio-religi Kota Kudus secara utuh. Aspek-aspek patriarki yang menggejala di tempat tersebut sangat bertolak belakang dengan realitas kehidupan para buruh dan santri yang bekerja sebagai buruh di PT. Djarum Kudus.

Dinamika kehidupan kaum buruh merupakan fakta yang bisa dicermati secara seksama bahwa keberadaan mereka berjalan di antara kepentingan dan kecenderungan baik personal maupun sosial dan juga korporasi. Secara sosial dapat dilihat, kehadiran budaya dalam lingkup pekerjaan mereka. Sebagai acuan akademik relasi budaya atas kehidupan buruh atas dampak industrialisasi, Moh. Masyhur Abadi (2009), mengetengahkan kajiannya tentang Islam, Tradisi dan Industrialisasi. Berbekal tesis industrialisasi tidak dapat dipisahkan dari modernisasi Barat, Moh. Masyhur Abadi menyimpulkan bahwa cacatcacat yang melekat pada modernisasi juga tidak dapat terhindarkan sebagai dampak dari industrialisasi.

Dunia industri yang merambah ke tengah-tengah kehidupan para santri yang bekerja sebagai buruh Pabrik Rokok di PT. Djarum Kudus tidaklah menjadi sebuah ancaman yang berarti dalam stabilitas kehidupan mereka. Keberlangsungan hidup survival of the fittest buruh Pabrik Rokok PT. Djarum Kudus tampak memiliki relasi terhadap dinamika perekonomian yang diserap oleh mereka. 
Kondisi ini diperkuat dengan stabilitas mereka untuk membangun struktur perekonomian yang progresif dalam laju ekonomi sosial yang cukup mengikat. Bersandar kepada analisis Nicholas J. White (2015) "The New Economic Policy in Malaysia: Affirmative Action, Ethnic, Inequalities and Social Justice" bahwa dalam perjalanannya, kebijakan ekonomi modern sudah bertumpu kepada kesadaran ekonomi untuk bersama. Dalam fokus penelitian yang diambilnya, masyarakat Malaysia, Nicholas J. White menjelaskan bahwa kemunculan etnosentrisme yang banyak dijumpai dalam kehidupan masyarakat Malaysia masa lalu, hal itu dilebur menjadi kesatuan dalam rangka membangun nasionalisme. Sementara itu, kewirausahaan yang bersifat personal hal tersebut dikembangkan pula melalui keterlibatan usaha yang juga diprakarsai oleh negara.

Konseptualisasi tentang etos kerja yang terjadi di masyarakat Jawa sebagaimana digambarkan oleh Setiawan dan Yoandinas di atas, hal tersebut menjelaskan kesadaran para perempuan Jawa atas korelasi setiap pekerjaan yang akan mereka jalankan di setiap waktu yang dijumpai. Kondisi ini menjadi gambaran budaya sosial di masyarakat yang menunjukkan bahwa mereka terus berjalan di antara tanggung jawab individu maupun sosial yang senantiasa perlu dipenuhi. Kekuatan rasa untuk memacu rutinitas pekerjaan tersebut menggambarkan kesadaran terstruktur mereka atas fakta-fakta sosial yang harus dipenuhi dan dikerjakan. Fakta yang berjalan di tengah-tengah mereka tersebut senada dengan tesis Abraham H. Maslow dengan penjelasannya bahwa kebudayaan yang memiliki sinergi lemah terhadap struktur sosial cenderung menggiring individu di dalamnya berkompetisi dalam ragam aktivitas. Sementara itu, kebudayaan dengan sinergi tinggi, menyediakan banyak hal kebutuhan yang akan diwujudkan secara bersama-sama. Maslow lebih lanjut memaparkan bahwa kondisi sosial yang memiliki keterkaitan sosial tinggi mendatangkan manfaat yang besar atas kegiatan-kegiatan yang bisa dilakukan bersama. Sementara itu, kondisi sosial yang memiliki keterkaitan yang lemah di antara pelakunya, sebuah kemanfaatan yang diperoleh oleh salah seorang di antara mereka akan dianggap kemenangan, dan orang lain yang ada di sekitarnya harus berjuang kuat untuk memperoleh kemenangan tersebut pula (Maslow, 1971: 194).

Penjelasan Maslow di atas meneguhkan kepada setiap individu bahwa derajat sosial yang sama di antara masing-masing, hal itu akan menopang secara kontributif kebutuhan bersama. Sementara itu, kesenjangan yang terjadi di antara individu, hal itu bisa mengakibatkan kompetisi yang kurang sehat di dalamnya. Untuk itulah, Maslow lebih lanjut menjelaskan realitas sosial dengan tingkat sinergi tinggi keberadaannya dapat melampaui polarisasi yang tercipta antara personalitas dan sebaliknya, kecenderungan personal dan altruisme, yang pada kenyataannya seseorang dalam eksistensinya senantiasa membutuhkan ongkos setimpal atas pekerjaan yang dilakukan. Realitas sosial dengan sinergi tinggi merupakan salah satu daripada kebajikan yang harus dipenuhi (Maslow, 1971: 194).

Eksplorasi yang dikemukakan Maslow di atas meneguhkan adanya kecenderungan pemenuhan hak dan kewajiban atas upah pekerjaan yang diharapkan oleh setiap pekerja. Altruisme seorang pekerja tetap disandarkan seutuhnya kepada pemenuhan dari upah pekerjaan yang dilakukan. Kenyataan ini menjadi semakin menarik, ketika pengamatan masing-masing pribadi diarahkan kepada fenomena kehidupan beragama dan bersosial masyarakat Kudus. Kesadaran akan beragama yang dianut oleh masyarakat Kota Kudus memang tampak berkembang kuat di antara pekerjaan-pekerjaan mereka sebagai buruh pabrik rokok. Kekuatan nilai-nilai dasar beragama dalam kehidupan masyarakat Kudus digambarkan oleh Lance Castles bahwa:

Kudus merupakan bagian daerah kantong pemungutan suara Islam lebih besar yang diperkirakan meliputi Kabupaten Demak, Kudus, dan Jepara. Di dalam ketiga kabupaten ini partai-partai Islam dianggap menerima mayoritas suara, sedangkan di daerah-daerah lain yang berbahasa Jawa di luar ketiga kabupaten ini partai-partai sekuler memenangkan lebih banyak suara. Eksistensi daerah kantong ini dengan ikatan Islam yang relatif kuat mungkin dapat dipertalikan dengan penyebaran agama itu yang sejak semula intensif, sejak daerah itu menjadi daerah inti 
kerajaan Demak abad ke-16, kerajaan Islam pertama di Jawa. Sebagai akibat perpaduan (mendamaikan kepentingan teologis dan estetis dalam banyak hal) yang telah ada di Jawa karena orientasi sinkretis golongan atas dan dikeluarkannya ulama dari kekuasaan, di daerah pesisir ini (seperti di ujung Jawa Timur). Karena perpaduan itu berkembang menjadi polarisasi selama abad ke-20 ini, mayoritas penduduk di daerah ini (meskipun hanya minoritas di Kota Kudus) memutuskan dirinya sendiri berada di pihak garis santri (Castles, 1982: 101-102).

Penjelasan Lance Castles tentang polarisasi sistem sosial-keagamaan yang terdapat di tengah-tengah masyarakat Kudus menjadi sebuah landasan untuk mengamati dinamika kehidupan mereka dengan perwujudan agama yang berjalan. Pada bagian ini penting menggarisbawahi pernyataan Mudjahirin Thohir yang melihat pengaruh ajaran agama terhadap kegiatan ekonomi masih merupakan pembahasan penting bagi bangsa Indonesia. Hal ini didasari oleh kenyataan bahwa masyarakat Indonesia adalah masyarakat religius. Sebagai masyarakat religius, ajaran-ajaran agama menempati posisi penting dalam mengatur kehidupan masyarakat manusia. Pada bagian selanjutnya, religiositas tersebut diharapkan menjadi pendorong terhadap tumbuhnya semangat kerja bagi para pemeluk agama dimaksud. Tidak kalah penting pula bahwa semangat kerja yang dilandasi moral agama, akan menciptakan suatu tatanan masyarakat yang makmur berkeadilan dan adil dalam kemakmuran (Thohir, 1999: 12).

Menyelami dua perspektif yang dikemukakan oleh dua ahli di atas, Lance Castles dan Mudjahirin Thohir dapat disimpulkan bahwa dinamika kehidupan masyarakat Kudus tergolong komunitas masyarakat yang berafiliasi varian abangan dan santri sebagaimana disampaikan Clifford Geertz:

"Kalangan abangan benar-benar tidak acuh terhadap doktrin, tetapi terpesona oleh detail keupacaraan. Sementara di kalangan santri, perhatian terhadap doktrin hampir seluruhnya mengalahkan aspek ritual Islam yang sudah menipis. Seorang abangan tahu kapan harus menyelenggarakan slametan dan apa yang harus jadi hidangan pokoknya-bubur untuk kelahiran, apam untuk kematian. Ia mungkin memiliki beberapa gagasan tentang apa yang dilambangkan oleh berbagai unsur dalam hidangan itu (sering kali juga tidak tahu dan hanya mengatakan bahwa ia menghidangkan bubur karena orang selalu menghidangkan bubur pada kesempatan seperti itu), tetapi ia akan sedikit kecewa kalau orang lain memberikan sebuah tafsiran yang berbeda. Ia memiliki toleransi dalam kepercayaan agama; katanya, "Jalan itu memang banyak". Kalau orang menyelenggarakan upacara pergantian tahap yang benar, orang itu bukanlah binatang. Kalau orang itu mengadakan slametan di bulan puasa, ia bukanlah orang kafir. Kalau orang mengirim baki untuk keperluan "bersih desa", ia tidak melakukan tindakan melanggar agama. Kalau orang tidak percaya pada makhluk halus atau mengira bahwa Tuhan tinggal di matahari, maka itu adalah urusannya sendiri" (Geertz, 2014: 178-179).

Kedua varian beragama sebagaimana dijelaskan oleh Clifford Geertz tersebut meskipun tidak tampak secara nyata dalam kehidupan masyarakat Kudus, namun kedua varian tersebut dalam perjalanan mereka senantiasa berinteraksi secara simultan terlebih dalam mengenalkan ritus-ritus keagamaan yang berjalan di tengah-tengah kehidupan mereka sehari-hari. Dialektika yang berjalan di antara dua varian sosial keagamaan di tengah-tengah masyarakat Kudus ini, pada akhirnya sebagai pencipta munculnya keberagamaan para buruh Pabrik Rokok PT. Djarum Kudus.

\section{METODE PENELITIAN}

Mendapatkan data penelitian yang menyeluruh, penelitian ini dikerangkakan sebagai melalui pendekatan kualitatif. Karena data penelitian ini terdapat di lapangan, maka desain antropologi budaya (Spradley, 2007: 7), kental dimunculkan dalam eksplorasi datanya. Unsur pengamatan sangat menentukan keberhasilan penelitian. Terlebih lagi, pengamatan berpartisipasi jelas dan penting bagi terlaksananya penelitian budaya (Endraswara, 2006: 16).

Berbekal analisis yang dikemukakan oleh David Jacobson, semua aspek yang muncul dari perilaku-perilaku kebudayaan yang diekspresikan oleh para buruh Pabrik Rokok PT. Djarum Kudus akan disatukan dalam rangka 
menghasilkan kesatuan argumen tentang realitas keberlangsungan hidup survival of the fittest mereka (Jacobson, 1991: 29).

Menyatukan berbagai perilaku budaya yang terdapat di tengah-tengah kehidupan buruh Pabrik Rokok PT. Djarum Kudus membutuhkan suatu pendekatan emis sehingga pada objektivitas hasil kajiannya tampak terlihat dengan sistematis. Pola pendekatan ini sebagaimana diungkapkan oleh Nanang Martono "emis merupakan sebuah pendekatan yang berorientasi pada perspektif internal, yaitu perspektif partisipan yang terlibat dan menjadi bagian studi" (Martono, 2016: 86). Deskripsi Nanang Martono tentang pendekatan emis sebagaimana diuraikannya juga hadir menjadi satu model pendekatan yang dilakukan oleh Pujo Semedi dengan penempatan dirinya di tengahtengah masyarakat yang diteliti. Pujo Semedi dengan tegas mengungkapkan bahwa lapangan penelitian yang diteliti ibarat tempat tinggal yang selalu hadir dikunjungi (Semedi, 2003: 20).

Pendekatan emis yang disampaikan oleh peneliti dalam rangka mengantarkan peneliti untuk menghasilkan data penelitian yang dilakukannya secara mendalam indepth interview terhadap beberapa informan yang sudah ditentukan (Sairin, 2006: 90). Mengamati dinamika kehidupan sosial dan kebudayaan yang berkembang di tengah-tengah buruh Pabrik Rokok PT. Djarum Kudus, pendekatan tentang aktualisasi diri self-actualization Abraham Harold Maslow dirancang sebagai bagian pendekatan dalam penelitian ini. Sebagaimana dijelaskannya, kebutuhan seseorang tidak akan mampu terlepas dari upaya dirinya mencapai kualitas. Aktualisasi individu berkaitan erat dengan pemenuhan-pemenuhan yang bisa diperoleh melalui ketercukupan diri atas hasrat hidup masing-masing. Seseorang akan merasa puas pada saat semua kebutuhan yang diinginkannya mampu diperoleh dan diraih dengan baik. Sebagaimana Maslow juga mencatat bahwa kepribadian seseorang akan terpenuhi hajat dirinya ketika individualitasnya terpenuhi. Hal ini sebagaimana juga akan terjadi pada diri seorang musikus yang akan merasakan kecukupan diri terpenuhi di saat dia membuat bait-bait lagu, begitu pula dengan seorang artis yang akan terpenuhi hasrat individualnya ketika dia berkreasi dalam aktivitas keaktrisannya, sebagaimana pula juga seorang sastrawan akan terpenuhi hasrat individualitasnya di saat dia menulis bait-bait puisi (Maslow, 1954: 46).

Penelitian ini merupakan penelitian lapangan yang dirancang untuk mengeksplorasi keberlangsungan hidup buruh Pabrik Rokok PT. Djarum Kudus. Penelitian ini dilangsungkan dari 2015 sampai 2018. Pendekatan kualitatif dalam penelitian antropologi memang bukanlah satusatunya pendekatan untuk dipakai sebagai desain operasional kajian. Namun, catatan yang dikemukakan Sjafri Sairin di atas meneguhkan bahwa penelitian-penelitian bidang antropologi sangat terkait dengan pendekatan kualitatif dalam perumusan analisis-analisis data yang dihasilkan. Metode pengumpulan data observasi partisipasi yang diajukan oleh peneliti dalam kerangka ini senada dengan penjelasan Suwardi Endraswara yang mengungkapkan pengamatan berpartisipasi dilakukan pada saat penyelenggaraan kebijakan budaya sedang menjalankan tugasnya. Analisis dilakukan secara deskriptif etnografis. Hal tersebut dilakukan secara terus menerus baik pada saat di lapangan dan setelah di lapangan. Proses analisis data yang terkumpul dengan metode ini dilakukan dengan cara mengatur, mengurutkan, mengelompokkan, memberi kode, dan mengategorikan data (Endraswara, 2016: 191). Metode wawancara (interview) menjadi bagian awal eksplorasi atas pengumpulan data penelitian (Koentjaraningrat, 1997: 129). Sebagai pembantu dari metode observasi dalam proses pengumpulan data, wawancara menjadi sebuah penjelas atas temuan-temuan data lapangan yang dijumpai. Hal ini sebagaimana disampaikan oleh Alan Barnard dan Jonathan Spencer "meskipun beberapa respons menghasilkan informasi-informasi penting, hal itu sering terjadi dalam konteks kebudayaan, namun semua itu membutuhkan analisis tepat, mengingat isi dari suatu wawancara tidak selamanya diambil secara literal (Such responses provide valuable information, usually culturally significant, but require careful analysis, for the content cannot always be taken literally)" (Barnard dan Spencer, 2010: 463).

Mengamati data penelitian yang terdapat di lapangan sebagai sebuah fenomena 
yang mengarah kepada kebudayaan masyarakat dalam beragama, bagian dari eksplorasi atas data-data tersebut dilakukan dengan teknik interpretasi. Kebudayaan sebagai salah satu aspek dalam kepentingan tersebut merupakan sebuah fenomena yang harus didekati melalui interpretasi guna memperoleh hakikat makna eksistensinya (Geertz, 1973: 5).

Interpretasi data penelitian secara menyeluruh dianalisis melalui teori fungsionalisme struktural A.R. Radcliffe-Brown dengan perspektifnya berbagai aspek perilaku sosial, bukanlah berkembang untuk memuaskan kebutuhan individual, tapi justru timbul untuk mempertahankan struktur sosial masyarakat. Struktur sosial yang dari suatu masyarakat adalah seluruh jaringan dari hubunganhubungan sosial yang ada (Ember dan Ember, 2006: 61). Untuk mengurai jaringan sosial ini secara utuh harus berpola di dalamnya analisis mendalam "thick description". penjelasan Clifford Geertz, thick description dijelaskan sebagai perpaduan antara "thinking and reflecting" berpikir dan berefleksi bersamaan dengan "the thinking of thoughts" menalar terhadap suatu pemikiran (Geertz, 1973: 6).

Analisis data dari deskripsi mendalam sebagaimana dijelaskan Geertz di atas juga dibenarkan oleh Mh. Nurul Huda atas pembacaannya bahwa dengan melakukan thick description, berarti seseorang menulis dengan metode itu untuk menangkap irama dan cara berpikir atau pola kerja sistem budaya. Pembaca ditarik untuk mengkaji banyak detail dan menempatkan dirinya dalam pengertian "hadir di sana" (being there), baik secara intelektual maupun emosional" (Huda, 2005: 213).

Lokasi penelitian yang terletak di beberapa wilayah Kabupaten Kudus menggiring peneliti untuk seutuhnya hadir dan memahami rutinitas kegiatan keagamaan yang berjalan di tengah-tengah kehidupan buruh Pabrik Rokok PT. Djarum Kudus. Beberapa aspek metodis yang tereksplor dalam metode penelitian di atas menjadi langkah taktis untuk keberlanjutan penelitian ini menjadi lebih efektif, efisien, dan terarah. Untuk itulah, dalam penelitian ini memerlukan kepekaan dan analisis mendalam peneliti sehingga dapat diolah semua data yang ada secara tepat dan sistematis.

\section{PEMBAHASAN}

Mengikuti pengajian Jumat pagi setelah Shalat Subuh menjadi rutinitas kegiatan sosial keagamaan yang diikuti oleh sebagian masyarakat Kabupaten Kudus. Pengajian model ini menjadi kegiatan umum yang sudah berjalan di tengah-tengah kehidupan masyarakat Kota Kudus. Berjuluk Kyai Tanpa Pesantren, Abdurrahman Mas'ud menyebutkan beberapa tokoh penting yang pernah mengisi ruang-ruang keagamaan masyarakat Kota Kudus. Sebut saja di antara mereka adalah KH. Sanusi, KHR. Asnawi, KH. Abdul Jalil Hamid Al-Falaky, KH. Yahya Arief, KH. Mawardi, KH. Arwani Amin, KH. Turaichan Adjhuri, KH. Ma'ruf Irsyad, KH. Ma'ruf Asnawi, dan KH. Sya'roni Achmadi. Para tokoh tersebut merupakan tokoh-tokoh penting yang mengisi ruang-ruang keagamaan masyarakat di Kota Kudus meskipun kenyataannya tidak seluruhnya memiliki pondok pesantren guna para santri menuntut ilmu (Mas'ud, 2013: 73-75).

Kedudukan Kota Kudus dengan model para kyainya yang tidak seluruhnya memiliki pondok pesantren sebagai sarana pendidikan moral dan perilaku (tarbiyatul ilm fi al-diin) kepada masyarakat digambarkan oleh Abdurrahman Mas'ud sebagai kota yang unik. Dalam catatannya Abdurrahman Mas'ud menjelaskan Kota Kudus memiliki kearifan lokal (local genius) yang mampu mengantarkannya dikenal di arena kesejagatan. Dari segi keberagamaan dan budaya, Abdurrahman Mas'ud menjelaskan Kota Kudus memiliki Sunan Kudus sebagai local model yang dalam penelitiannya digambarkan sebagai:

Kudus muslim myth and ethics are mostly inherited by their ideal leader, Sunan Kudus. Santri and Dagang are almost identical in this community. This could be interpreted from their 'Ulama doctrines in which most of Kudus muslim recall: "seek for your living as though you would live forever, and obtain your heaven as though you would die tomorrow". Shortly, to work hard and to worship at the same time is out of question here. This habit which would be attributed to their ideology has been historically and culturally institutionalized (Mas'ud, 2013: 70). 
Gambaran mitos dan etika yang tertanam dalam diri masyarakat Kudus sebagaimana digambarkan oleh Abdurrahman Mas'ud di atas menandai kehidupan keagamaan masyarakat sebagai fakta kesejarahan yang tampak terlihat kenyataannya sampai saat ini. Fakta kesejarahan yang ada tertulis dengan kuat pada kedudukan Kota Kudus adalah sebagai Kota Santri. Eksistensi ini termaktub dengan jelas dibuktikan dengan berdirinya salah satu peninggalan sejarah Walisongo di Kota Kudus. Masjid al-Aqsha atau umum dikenal dengan sebutan Masjid Menara Kudus merupakan peninggalan Raden Dja'far Shodiq yang lebih dikenal dengan sebutan Sunan Kudus. Dalam catatan Lombard disebutkan bahwa "Masjid Menara Kudus telah dibangun pada Abad ke-16 tepatnya tahun 1549 M. Penyebutan daerah ini dengan sebutan Kota Kudus dikuatkan oleh Lombard sebagai bentuk pengacuan pada alQuds (Nama Arab untuk Yerussalem) merupakan kota keagamaan, kota suci, dan mempunyai masjid yang besar lagi indah, Masjid al-Aqsha" (Lombard, 2005: 54).

Meneguhkan simpulan Lombard di atas, Lance Castles juga mencatat pemilihan nama Kudus dibuat sebab Kota Kudus telah menjadi pusat beberapa macam agama pada masa praIslam dan diubah oleh Sunan Kudus yang pada waktu itu merupakan seorang komandan di lingkungan Kerajaan Demak untuk penggunaan Islam (Castles, 1982: 76). Kesucian Kota Kudus ini juga tergambar dari kuatnya masyarakat Kota Kudus yang masih mempertahankan diri tidak menyembelih sapi perwujudan dari toleransi keberagamaan atas agama Hindu yang lebih awal eksis (Dijk, 1998: 218-235).

Keragaman kehidupan sosial keagamaan masyarakat Kota Kudus terpancar jelas dengan bertempatnya beberapa tempat beribadah yang ada di tengah-tengah kehidupan masyarakatnya. Bertempatnya aneka macam tempat ibadah ini memperjelas identitas sosial keagamaan masyarakat Kudus yang dipenuhi dengan toleransi yang cukup tinggi. Meskipun pada tahun 1918 Lance Castles mencatat terjadinya konflik etnis di Kota Kudus (Castles, 1982: 103), namun peristiwa tersebut tidak menyebabkan munculnya upaya intoleransi di masa-masa kini. Kehidupan masyarakat Kota
Kudus senantiasa terjaga dengan kuatnya tingkat solidaritas masyarakat yang hidup di dalamnya.

Gambaran realitas sosial keagamaan yang berkembang di Kota Kudus pada masa lalu juga disimpulkan oleh Lance Castles tentang pemisahan wilayah yang terdapat di bagian Barat Kulon dan bagian Timur Wetan. Kudus Kulon, sebelah Barat sungai kecil yang mengalir melalui kota, kadang disebut juga kota tua dan berisi makam wali. Kudus Wetan, terletak di sebelah timur sungai, tempat kediaman bupati dan kebanyakan kantor pemerintahan, sekarang menjadi kota yang lebih besar dan lebih sibuk. Hingga tahun 1965, penduduk setempat kadangkadang melukiskan pembagian itu dari sudut perbedaan politik: Kudus Barat Kulon kepunyaan Masyumi dan Kudus Timur Wetan kepunyaan Komunis (Castles, 1982: 78-79).

Perbedaan kewilayahan yang terdapat di Kota Kudus sebagaimana dijelaskan oleh Lance Castles untuk masa kini, tidak ekstrem penampakannya. Kota Kudus masa kini lebih membaur kehidupan sosial keagamaan masyarakatnya dengan bertempatnya pondokpondok pesantren yang ada di kawasan Kudus Barat Kulon dan Kudus Timur Wetan. Meskipun dalam catatan Castles diferensiasi kewilayahan yang terjadi karena afiliasi politik, namun dalam pertumbuhan terkini aspek politik yang berkembang tidak menjadi dasar pemicu antara dua wilayah dalam satu kawasan administratif tersebut.

Mengamati pertumbuhan kewilayahan yang ada, Kota Kudus sebagai lokasi bertempatnya para buruh Pabrik Rokok PT. Djarum Kudus merupakan sebuah wilayah yang cukup unik. Keunikan tersebut tampak dari keberadaan wilayahnya yang tidak terlalu luas dari luas wilayah dengan cakupan 9 kecamatan 123 Desa dan 9 kelurahan, serta 716 Rukun Warga (RW), 3.764 Rukun Tetangga (RT) dan 420 Dukuh/Lingkungan. Kecamatan Kota merupakan kecamatan dengan jumlah desa/kelurahan terbanyak yaitu 25 desa/kelurahan sedangkan Kecamatan Bae adalah kecamatan dengan jumlah desa terkecil (10 Desa) (BPS Kudus, 2015: 31).

Letak kewilayahan yang tergolong kecil menjadikan Kota Kudus dalam aspek administratifnya mudah untuk dijangkau dari 
beberapa wilayah sekitar. Sebelah Utara berbatasan dengan Kabupaten Jepara dan Kabupaten Pati, sebelah Timur berbatasan dengan Kabupaten Pati, sebelah Barat berbatasan dengan Kabupaten Jepara dan Kabupaten Demak, dan di sebelah Selatan berbatasan dengan Kabupaten Grobogan, Kabupaten Pati, serta Kabupaten Demak. Secara ke wilayah, luas Kabupaten Kudus berkisar 42.515.64 Ha. Kabupaten Kudus terletak di antara $110^{\circ} 36^{\prime}$ dan $110^{\circ} 50 \mathrm{BT}$ (Bujur Timur) serta $6^{0} 51^{\prime}$ dan $7^{0} 16^{\prime}$ LS (Lintang Selatan) (BPS Kudus, 2015: 7-10).

Luas wilayah Kudus yang tidak cukup luas dengan cakupan 42.515.64 Ha luas kewilayahannya, kota ini menjadi mudah untuk dijangkau oleh banyak masyarakat melalui wilayah-wilayah terdekat atau sekitar. Gambaran dari Kota Kudus terkini juga tidak jauh berbeda dengan deskripsi yang disampaikan oleh Lance Castles pada tahun-tahun penelitiannya dengan menjelaskan Kota Kudus merupakan kota kecil yang hanya mempunyai penduduk 75.000 orang pada tahun 1961 . Castles lebih lanjut membandingkan jumlah ini dengan tesis yang disampaikan oleh Clifford Geertz bahwa Kudus tiga kali lebih besar dari Mojokuto (Castles, 1982: 72).

Jumlah penduduk yang berjumlah tiga kali lebih besar daripada Mojokuto sebagaimana tesis Geertz di atas, hal itu tidak pernah menjadikan Kudus sebagai ibu Kota Provinsi atau keresidenan. Kudus juga tidak mempunyai organisasi sendiri-daerah kota semata-mata adalah satu di antara sembilan kecamatan ke dalam mana kabupaten dibagi. Selain dari status administratifnya, keadaan sosial tidak memenuhi syarat Kudus sebagai kota besar. Beberapa ratus meter dari jalan-jalan teramai seseorang dapat menemui kampung-kampung dalam bentuk pedesaan. Selain dari orang Cina dan Arab, Kota Kudus tidak berpenduduk orang asing. Bahkan anggota golongan suku bangsa Indonesia di luar Jawa (Minangkabau, Manado, Ambon) yang merupakan bagian terkemuka di kota-kota besar seperti Jakarta dan Bandung, sangat sedikit di Kudus. Pertentangan tajam di antara kompartemen modern dan tradisional, di Kudus tidak begitu menyolok (Castles, 1982: 73).
Keberadaan pendatang yang tergolong kecil di Kota Kudus, "menggiring" masyarakat Kudus mengembangkan potensi kewilayahannya secara maksimal. Bersandar kepada peninggalan yang diwariskan oleh para pendahulu Kota Kudus, Sunan Kudus sebagaimana dicatat oleh Nur Said merupakan seorang saudagar. Sebagai seorang saudagar dan dikenal ulet dalam usaha yang dijalankan, menjadi inspirasi berharga masyarakat Kudus untuk mengembangkan usaha di daerah. Pertanda keuletan ini dicatat oleh Nur Said dengan misi dakwah yang dijalankan Sunan Kudus tidak terlepas dari jaringan lokal maupun global dalam dunia saudagar (Said, 2010: 38).

Pranata keagamaan yang terdapat di tengah-tengah kehidupan masyarakat Kudus, menjadi inspirasi kuat yang mendorong mereka berjuang hidup sejahtera, bekerja dengan ulet, dan memacu perekonomian keluarga dengan rapi. Dasar atas usaha ini dilakukan oleh masyarakat Kudus bersandar kepada penjelasan para Kyai Kudus akan kekuatan dari firman Allah Swt., pada QS. Al-Qashash, [28]: 77:

"Dan carilah pada apa yang telah dianugerahkan Allah kepadamu (kebahagiaan) negeri akhirat, dan janganlah kamu melupakan bagianmu dari (kenikmatan) duniawi dan berbuat baiklah (kepada orang lain) sebagaimana Allah telah berbuat baik, kepadamu, dan janganlah kamu berbuat kerusakan di (muka) bumi. Sesungguhnya Allah tidak menyukai orang-orang yang berbuat kerusakan"(DEPAG, 1993: 623).

Kekuatan dari firman Allah Swt., di atas, terhadap pola kehidupan masyarakat Kudus dikukuhkan oleh Abdurrahman Mas'ud dengan menjelaskan bahwa ulama legendaris Kudus, KHR. Asnawi yang meninggal 1959, memiliki pandangan yang tidak beda. KHR. Asnawi tercatat sebagai kaum santri (middle class) yang melakukan perubahan-perubahan fundamental, dalam kehidupan berekonomi, berpolitik, dan berbangsa (Mas'ud, 2013: 71).

Kehidupan kaum santri di Kudus merupakan sebuah gambaran sosial kaum santri yang mampu membantah asumsi umum dan stereotyping yang mengatakan bahwa kerja keras tidak dimiliki kaum santri. Mengaji (learn) 
dan dagang (trade) merupakan tradisi penting yang menggugah kehidupan masyarakat santri Kudus sebagai implikasi atas interpretasi dan pembacaan mereka pada ayat-ayat alquran tentang usaha hidup di dunia menuju ke akhirat (Mas'ud, 2013: 72). Slogan Gusjigang sebagai filosofi hidup masyarakat Kudus menginternalisir secara seksama dalam keseharian hidup mereka.

Tingkat keberlangsungan kehidupan santri dalam masyarakat Kudus memberikan warna kuat atas pola-pola sosial yang dijalankan di tengah-tengah kehidupan masyarakatnya. Fakta ini bersandar kepada dinamika kehidupan para santri yang identik dengan sikap pasrah, tawakal, dan patuh atas ajaran-ajaran agama. Menggambarkan kondisi ini, Mudjahirin Thohir menegaskan bahwa berwatak toleran merupakan ciri umum yang ter sosialisasikan dan terekspresikan dalam kehidupan pondok pesantren tradisional (Thohir, 2013: 67). Potret ini sekaligus memperjelas realitas kehidupan santri masyarakat Kudus sebagai pribadi-pribadi yang penuh sikap pasrah, patuh, dan taat pada ajaran-ajaran agama.

Memperjelas tesis Mudjahirin Thohir, kehidupan bercirikan santri menjadi potret sejahtera di banyak kehidupan masyarakat Kudus. Filosofi Gusjigang sebagaimana gambaran Abdurrahman Mas'ud di atas merupakan gambaran umum yang bisa dilihat dalam dinamika kehidupan masyarakat Kudus. Potret kehidupan ini memang bukanlah gambaran satu-satunya yang bisa dilihat dan disaksikan. Masyarakat industri menjadi gambaran lain pola kehidupan masyarakat mereka. Profesi sebagai buruh menjadi potret lain yang bisa dilihat dan disaksikan. Masyarakat Kudus banyak juga yang terlibat dalam profesi mereka sebagai buruh di pabrik-pabrik rokok yang ada di Kota Kudus.

Kesejahteraan yang tergambar dalam kehidupan kaum santri di Kota Kudus tidaklah menjadi fenomena tunggal yang bisa diderivasikan ke dalam kehidupan kaum buruh pabrik rokok. Keberadaan mereka di pabrik sebagai pekerja menjadikan beberapa aktivitas kehidupan yang dijalani terkendala dan ditinggalkan. Hal ini secara sosiologis digambarkan oleh Zainal Asikin bahwa seorang buruh adalah pribadi yang tidak bebas. Keberadaan dirinya menandakan sebagai pribadi yang tidak mempunyai bekal hidup yang lain selain tenaganya. Untuk selanjutnya, pada suatu kesempatan mereka akan dihadapkan kepada rasa terpaksa untuk menerima hubungan kerja dengan majikan meskipun memberatkan (Asikin, 2014: 5). Keberadaan ini menjadi fenomena yang dapat dijumpai dalam dinamika kehidupan buruh Pabrik Rokok PT. Djarum di Kota Kudus.

Ironi kehidupan buruh Pabrik Rokok PT. Djarum Kudus digambarkan oleh salah seorang masyarakat sebagai buruh yang terikat atas aturan-aturan umum dan khusus dari pabrik. Kemunculan dari kondisi ini menggiring masyarakat melabelkan Kuli Raup atas intensitas kerja mereka yang sangat mengikat.

Wong-wong kene iku pak nek kon kerja neng pabrik, lagi bar raup langsung pudal menyang pabrik.

Orang-orang di sini pak kalau bekerja di pabrik, baru saja mereka basuh muka, langsung saja berangkat ke pabrik (Wawancara dengan TGS, 12 Agustus 2015).

Intensitas pekerjaan yang begitu menyita menggiring para buruh kepada pilihan yang sama-sama tidak menguntungkan. Waktu pagi yang perlu dipersiapkan untuk keluarga tersita dengan ketepatan waktu kehadiran mereka di pabrik. Dilema ini tetap dijalankan secara seksama, karena kesadaran akan kebutuhan pekerjaan ini untuk terus dilanjutkan dan dipenuhi. Mereka yang berstatus sebagai buruh Pabrik Rokok PT. Djarum Kudus tidak semuanya memiliki produktivitas yang tinggi. Hal ini bisa dilihat pada kelompok angkatan kerja paruh waktu. Angkatan kerja paruh waktu sebagaimana digambarkan Melania Kiswandari pendayagunaannya belum optimal. Rendahnya tingkat pendayagunaan tenaga kerja tersebut mengakibatkan rendahnya penghasilan tenaga kerja dan pendapatan rata-rata rumah tangga (Kiswandari, 2014: 33).

Meskipun di banyak sorotan peneliti dan publik ekspektasi perusahaan terhadap kaum buruh sangat disayangkan, namun dalam sistem manajemen yang berjalan di Pabrik Rokok PT. 
Djarum Kudus mereka menerapkan sebuah pakta integritas. Sebagai salah satu perusahaan publik yang mementingkan pelayanan terbaik bagi segenap konsumennya, PT. Djarum Kudus menerapkan kebijakan mutu yang tertuang dalam Djarum Quality Management System. Dalam komitmen tersebut tercatat PT. Djarum Kudus sebagai perusahaan yang bergerak di bidang industri rokok dan bertanggung jawab atas segala upaya terbaik bagi tercapainya keberhasilan jangka panjang, keutamaan mereka adalah menjaga aspek kualitas produk, lingkungan, keselamatan dan kesehatan kerja, sehingga tercapai produk yang berkualitas tinggi, lingkungan yang tidak tercemar, aman dan sehat terhindar dari bahaya-bahaya dan risiko terkait aspek lingkungan, keselamatan dan kesehatan kerja. Target-target utama dalam produksi perusahaan ini adalah; 1) Menghasilkan produk-produk yang berkualitas tinggi secara konsisten dan inovatif untuk memuaskan konsumen; 2) Mengendalikan kegiatan usaha agar tidak menimbulkan dampak yang merusak lingkungan hidup; 3) Memberikan perlindungan keselamatan dan kesehatan kerja bagi setiap insan yang terlibat di dalamnya; 4) Memberikan perlindungan terhadap aset perusahaan; 5) Mematuhi dan menerapkan peraturan perundangan dan persyaratan lainnya mengenai aspek kualitas, lingkungan serta keselamatan dan kesehatan kerja. ${ }^{1}$

Memfasilitasi pekerjaan para buruh yang tergabung dalam lingkaran kerja di Pabrik Rokok PT. Djarum Kudus, perusahaan memberikan peraturan-peraturan mengikat yang dirancang demi menghasilkan mutu pekerjaan prima para buruh yang ada. Pada bagian yang lain, demi menghasilkan sumber perekonomian yang efektif keluarga, para santri yang bekerja sebagai buruh Pabrik Rokok di PT. Djarum Kudus secara seksama menyikapi pendapatan ekonomi yang ada dengan usaha-usaha

1 Jaminan terhadap mutu manajemen dirumuskan dan ditanda tangani bersama oleh para pimpinan di lingkungan PT. Djarum, tertanggal, 1 Februari 2016. PT Djarum memastikan selalu melakukan peninjauan ulang dan perbaikan berkelanjutan terhadap "Djarum Quality Managemen System”, dengan kesepakatan-kesepakatan; Robert Budi Hartono selaku Chief Executive Officer; Victor R Hartono selaku Chief Operating Officer HRD sampingan yang dilakukan di rumah oleh keluarga masing-masing. Diversifikasi usaha menjadi alternatif yang efektif untuk menopang pendapatan ekonomi yang mencukupi.

Menjembatani pendapatan ekonomi yang dihasilkan oleh para buruh dalam setiap hari mereka bekerja di pabrik, para buruh juga melakukan pembagian kerja yang cukup efektif bersama dengan keluarga mereka di rumah. Pekerjaan yang mereka jalankan di rumah juga menjadi daya topang perekonomian sehingga kebutuhan-kebutuhan dasar yang perlu mereka wujudkan juga bisa dihasilkan secara maksimal.

Kagem menopang ekonomi kulo Pak, ibu nggeh sadehan wonten dalem. Gaji kulo saking pabrik boten nate disuwun kejabane nembe butuh.

Untuk menopang ekonomi saya pak, ibu yang berjualan di rumah. Gaji saya dari pabrik tidak pernah beliau minta kecuali saat ada kebutuhan (Wawancara dengan SPH, tanggal 10 Maret 2018).

Kesadaran untuk membangun pekerjaan yang bisa menopang ekonomi keluarga menjadi pandangan umum yang muncul dalam partisipasi kerja para santri yang bekerja sebagai buruh di PT. Djarum Kudus. Pertahanan mereka untuk selalu berdisiplin hidup di pabrik menjadi pandangan umum yang diekspresikan karena mereka menyadari bahwa bekerja di PT. Djarum Kudus tidak mengganggu atas stabilitas ibadah yang mereka jalankan. Hal ini juga bertitik tolak kepada kondisi pabrik yang memenuhi secara utuh fasilitas-fasilitas ibadah yang memang dibutuhkan. Pembangunan mushalla sebagai tempat ibadah dan penyiapan mukena untuk beribadah menjadi bagian menyatu yang dilakukan oleh pihak pabrik bagi kenyamanan para buruh di PT. Djarum Kudus.

Director; Martin B Hartono selaku Business Technology Diretcor; M. Ismawan Basorie selaku Finance Director; Hadi Wasito selaku Research and Development Director Purchasing Director; Thomas Budi Santoso selaku Production Director; dan Honky Harjo selaku Marketing and Business Development Director. 


\section{PENUTUP}

Masyarakat Kota Kudus yang banyak dikenal publik sebagai masyarakat religius tidak bisa dipisahkan dari keberadaan Pabrik Rokok PT. Djarum Kudus di tengah-tengah kehidupan mereka. Perusahaan ini menjadi sumber ekonomi efektif bagi kebanyakan masyarakat di Kota Kudus. Dalam rangka mempertahankan diri sebagai santri dan buruh pabrik, masyarakat Kota Kudus menyadari pentingnya mereka berinteraksi dengan kehidupan disiplin di pabrik dalam rangka meneguhkan bahwa mereka adalah para pribadi yang didik dan didedikasikan melalui filosofi Gusjigang.

Menjembatani perekonomian keluarga yang mereka jalankan, para santri yang bekerja sebagai buruh di PT. Djarum Kudus secara seksama membuat diversifikasi usaha bersama keluarga mereka di rumah. Strategi ini menjadi efektif bagi keberlangsungan mereka karena mereka bisa memenuhi kebutuhan keluarga secara maksimal tanpa merasa terbebani dengan pendapatan upah yang diperoleh dari perusahaan. Pada bagian yang lain, mereka juga merasakan tingkat kenyamanan bekerja karena pemenuhan keagamaan mereka dapat terlaksana dengan baik. Pabrik memberikan fasilitas ibadah yang representatif demi menciptakan kenyamanan bekerja selama berada di perusahaan.

\section{UCAPAN TERIMA KASIH}

Laporan penelitian tentang "Agama Kuli Raup-Strategi "Survival of the Fittest" Santri Pekerja Buruh Pabrik Rokok di PT. Djarum Kudus_-", telah paripurna. Selesainya penelitian ini tentu tidak bisa dilepaskan dari sumbangan beberapa pihak, di antaranya Rektor IAIN Kudus yang telah memberikan izin atas pelaksanaan penelitian ini. Selanjutnya pula, Kepala Lembaga Penelitian dan Pengabdian kepada Masyarakat IAIN Kudus yang telah merekomendasikan penelitian ini untuk dilanjutkan dalam perumusannya.

\section{DAFTAR PUSTAKA}

Asikin, Zainal. 2014. "Pengertian, Sifat dan Hakikat Hukum Perburuhan" dalam Dasar-Dasar Hukum Perburuhan, ed. Zainal Asikin, Jakarta: Rajawali Pers.

Ath-Thabari, Abu Ja'far. 2000. Jami' al-Bayan fi Ta'wil al-Qur'an. Riyadh: Muassasah Arrisalah.

Badan Pusat Statistik Kabupaten Kudus. 2015. Kudus dalam Angka. Kudus: BPS Kabupaten Kudus.

Bambang T.D., dkk., ed. 2015. Buruh Menuliskan Perlawanan (Yogyakarta: Lembaga Informasi Perburuhan Sedane (LIPS) Bekerjasama dengan Tanah Air Beta).

Barnard, Alan dan Jonathan Spencer. 2010. Encyclopedia of Social and Cultural Anthropology, Second Edition. New York: Routledge, 2010.

Castles, Lance. 1982. Tingkah Laku Agama, Politik dan Ekonomi di Jawa: Industri Rokok di Kudus, ter. J. Sirait. Jakarta: Sinar Harapan.

Departemen Agama Republik Indonesia. 1993. Al-Qur'an dan Terjemahnya, terj. Yayasan Penerjemah al-Qur'an Direvisi oleh Lajnah Pentashih Mushaf al-Qur'an Departemen Agam RI. Semarang: AlWaah.

Dhofier, Zamakhsyari. 2011. Tradisi Pesantren-Studi Pandangan Hidup Kyai dan Visinya Mengenai Masa Depan Indonesia-, Jakarta: LP3ES.

Dijk, Kees Van. 1998. "Dakwah and Indigenous Culture; The Dissemination of Islam" dalam Bijdragen Tot de Taal-, Land-en Volkenkunde, Globalization, Localization and Indonesia 154, No. 2. Leiden, 218235.

Ember, Carol R. dan Melvin Ember. 2006. "Teori dan Metoda Antropologi Budaya" dalam Pokok-Pokok Antropologi Budaya, ed. T.O. Ihromi. Jakarta: Yayasan Obor Indonesia. 
Endraswara, Suwardi. 2006. Metodologi Penelitian Kebudayaan. Yogyakarta: Gadjah Mada University Press.

Geertz, Clifford. 1973. The Interpretation of Cultures. New York: Basic Books.

Geertz, Clifford. 2014. Agama Jawa: Abangan, Santri, Priyayi dalam Kebudayaan Jawa, terj. Aswab Mahasin dan Bur Rasuanto. Jakarta: Komunitas Bambu.

Huda, Mh. Nurul. 2005. "Budaya sebagai Teks: Narasi dan Hermeneutik", dalam TeoriTeori Kebudayaan, Mudji Sutrisno dan Hendar Putranto, ed. Yogyakarta: Kanisius.

Jacobson, David. 1991. Reading Ethnography. Albany: State of New York Press.

Kiswandari, Milania. 2014. "Pengerahan dan Pendayagunaan Tenaga Kerja" dalam Asas-Asas Hukum Perburuhan, ed. Aloysius Uwiyono, dkk., Jakarta: Rajawali Pers.

Koentjaraningrat, 1997. "Metode Wawancara" dalam Metode-Metode Penelitian Masyarakat Edisi Ketiga, ed. Koentjaraningrat. Jakarta: Gramedia.

Kuncoro, Mudrajad. "The Dynamic of Clove Cigarette Industrial Clusters ini Indonesia," Global Advanced Research Journal of Management and Business Studies. Juli 2014, 296-314.

Lombard, Denys. 2005. Nusa Jawa: Silang Budaya Jaringan Asia, Jilid, II, terj. Winarsih Partaningrat Arifin, dkk., Jakarta: Gramedia.

Martono, Nanang. 2016. Metode Penelitian Sosial Konsep-Konsep Kunci. Jakarta: Rajawali Pers.

Mas'ud, Abdurrahman. 2013. Kyai Tanpa Pesantren (Potret Kyai Kudus). Yogyakarta: Gama Media.

Maslow, Abraham H. 1971. The Farther Reaches of Human Nature (New York: Viking Press. PDF e-book.
Maslow, Abraham Harold. 1954. Motivation and Personality, (New York: Harper \& Row Publishers, 1954), PDF e-book, 46.

Mudjahirin Thohir, Wacana Masyarakat dan Kebudayaan Jawa Pesisiran. Semarang: Bendera.

Northcutt, Wendy. 2001. The Darwin Awards Survival of the Fittest, (New York: The Dutton Publishing Group.

Peraturan Pemerintah Nomor 78 Tahun 2015 tentang Pengupahan. Bab II Kebijakan Pengupahan Pasal 3 Ayat 1.

Plummer, Ken. 2013. Sosiologi The Basic, terj. Nanang Martono dan Sisworo Jakarta: Rajawali Press.

Said, Nur. 2010. Jejak Perjuangan Sunan Kudus dalam Membangun Karakter Bangsa. Bandung: Brillian Media Utama.

Sairin, Sjafri. 2002. Pengantar Antropologi Ekonomi. Yogyakarta: Pustaka Pelajar.

Sairin, Sjafri. 2006. "Yang Diingat dan Dilupakan, yang Teringat dan Terlupakan-Social Memory dalam Studi Antropologi-“, dalam Esei-Esei Antropologi-Teori, Metodologi \& Etnografi-, ed. Heddy Shri AhimsaPutra. Yogyakarta: Kepel Press.

Semedi, Pujo. 2003. Close to Stone Far from the Throne; The Story of a Javanese Fishing Community 1820s-1990s. Yogyakarta: Benang Merah, 2003.

Setiawan, Sigit Budhi. dan Marlutfi Yoandinas, 2013. Mereka yang Melampaui-Konsep Panjang Umur, Bahagia, Sehat, dan Tetap Produktif. Yogyakarta: Pustaka Sempu dan Layar Nusa, 2013.

Spradley, James. 2007. Metode Etnografi, terj. Misbah Zulfa Elizabeth. Yogyakarta: Tiara Wacana.

Thohir, Mudjahirin. 2006. Orang Islam Jawa Pesisiran, Semarang: Fasindo Press.

Thohir, Mudjahirin. 2013. Multikulturalisme Agama, Budaya, dan Sastra. Semarang: Gigih Pustaka Mandiri. 
186 | Jurnal “Al-Qalam” Volume 25 Nomor 1 Juni 2019 